\title{
Protecting the Rights of a Child Offender: The Bangladesh Perspective
}

\author{
Tahsin Khan \\ Lecturer, Department of Law \& Justice, Southeast University, Bangladesh
}

\begin{abstract}
Child offenders may not always possess the maturity to realise the severity of their acts. In addition to that if child offenders are allowed to be in contact with adult offenders, they are likely to be affected negatively. Realising the special needs of child offenders, the Children Act, 1974 was enacted. However, with the adoption of the United Nations Convention on the Rights of the Child (UNCRC), many of the provisions of the Children Act, 1974 became obsolete. Bangladesh became a state party to the UNCRC subsequently and in order to meet the international standards, the Children Act, 2013 was enacted. Some of the most noteworthy provisions of the Act contain prohibition on joint trial, prohibition on public trials, prohibition on making particulars public, provisions relation to setting up child affairs desk at the police station, right to legal aid, determination of the age, looking at the offender instead of looking at the offence, restraint on imposition of certain punishments, diversion, family conference and alternative dispute resolution, establishing child development centres and certified institutes, periodic review and release etc. However, unfortunately not all of these provisions are always complied with, nevertheless, Bangladesh can be said to be on the right track to protect the rights of child offenders.
\end{abstract}

Keywords:- Beijing Rules, Children Act 2013, Havana Rules, Riyadh Guidelines and the UNCRC.

\section{INTRODUCTION:}

Bangladesh is a country having a population of one hundred and fifty million people and almost half of the population is constituted with the children. ${ }^{1}$ Due to their young age, children who come in conflict with the law may not have possessed the maturity to realise the gamut of their acts. Besides they should not be exposed to the company of adult offenders which is likely to have an aggravating impact on them. Realising this the High Court Division of the Supreme Court of Bangladesh observed in Bimal Das v State: 'Juvenile courts are created in recognition of special needs of the young offenders so that a child appearing before the court does not come into contact with adult offenders or come out of trial with unnecessary and unavoidable stigma to his name'. ${ }^{2}$ The constitution of Bangladesh itself while provided for ensuring equality before law and prohibited discrimination among citizens, also encouraged the state to make special arrangements in favour of children. ${ }^{3}$ As a result the Children Act, 1974 was enacted with the aim of modifying the scattered laws relating to the children with special focus on the child offenders. The Children Act, 1974 has called for separate judicial proceedings as well as for reintegration of child offenders in the society. ${ }^{4}$ However, the issue of children justice jurisprudence became truly international with the United Nations Convention on the Rights of the Child (UNCRC), $1989^{5}$ setting the norms to be adhered to. In addition to the UNCRC, three other United Nations documents, namely: the Beijing Rules ${ }^{6}$, the Riyadh Guidelines ${ }^{7}$ and the Havana Rules ${ }^{8}$, expressly dealing with the children coming into conflict with the law were adopted. Bangladesh immediately became a state party to the UNCRC and some of the provisions of the Children Act, 1974 became obsolete. However, it was observed in H.M. Ershad v

\footnotetext{
${ }^{1}<$ http://www.humanium.org/en/asia-pacific/bangladesh/> accessed 16 May 2016.

${ }^{2}$ [1994] DLR 460 (HCD).

${ }^{3}$ The Constitution of the People's Republic of Bangladesh, Article 28.

${ }^{4}$ Anisur Rahman, 'Realization of the Rights of a Child Offender Judicial Activism in Bangladesh' (2008) 9

Journal of Human Rights Summer School 232.

${ }^{5}$ UN General Assembly, Convention on the Rights of the Child, 20 November 1989, United Nations Treaty Series, vol. 1577, p. 3.

${ }^{6}$ UN General Assembly, United Nations Standard Minimum Rules for the Administration of Juvenile Justice

("The Beijing Rules"): resolution / adopted by the General Assembly., 29 November 1985, A/RES/40/33.

${ }^{7}$ UN General Assembly, United Nations Guidelines for the Prevention of Juvenile Delinquency (The Riyadh

Guidelines): resolution / adopted by the General Assembly. , 28 March 1991, A/RES/45/112.

${ }^{8}$ UN General Assembly, United Nations Rules for the Protection of Juveniles Deprived of Their Liberty: resolution / adopted by the General Assembly., 2 April 1991, A/RES/45/113.
}

DOI: $10.9790 / 0837-2203064754 \quad$ www.iosrjournals.org $\quad 47 \mid$ Page


Bangladesh that international instruments are not directly enforceable in national courts as long as the provisions are not incorporated in the domestic law. ${ }^{9}$ Therefore, it was imperative to modify the exiting Children Act, 1974 in order to live up to the international standard. Accordingly, the Children Act, 2013 was enacted upgrading the previous provisions and incorporating some new provisions altogether. Generally speaking, the Children Act, 2013 has adopted two approaches to protect the rights of the child offenders, namely: (i) protective approach and (ii) welfare approach. ${ }^{10}$ This essay is an attempt to evaluate the protections afforded to a child offender in the perspective of Bangladesh. In between evaluating these protections, critical evaluation of some of the noteworthy judgments delivered by the judiciary of Bangladesh will be made.

\section{WHO IS A CHILD OFFENDER?}

Unfortunately, laws dealing with the definition of a child in Bangladesh are not uniform. Some of the definitions of a child under different laws of Bangladesh have been enumerated below:

- According to the Children Act, 1974 (which is now repealed by the Children Act, 2013), a child is a person under the age of sixteen years. 11

- According to the Prevention of Repression of Women and Children Act, 2002, a child is a person who has not exceeded the age of sixteen years. ${ }^{12}$

- According to the Children Act, 2013, a child is a person under the age of eighteen years. ${ }^{13}$

However, the Children Act, 2013 apparently eradicates all ambiguity as it stipulates that it is a special law with overriding effect, and notwithstanding anything contained to the contrary in any other law in force, it will be given preference. ${ }^{14}$ It is clearly an attempt to put the children justice jurisprudence of Bangladesh in consonance with the UNCRC which lays down in Article 1 that every human being below the age of eighteen years should be considered as a child.Therefore, it can be asserted that a child is every person under the age of eighteen and a child offender is a child who has been found to have come in conflict with the law.

Nevertheless, despite defining a child as well as a child offender, the age at which criminal liability will accrue remains a matter of hot debate. The UNCRC has required the state parties to set a minimum age below which a child shall be deemed to be incapable of infringing the penal law but does not specifically mention any minimum age for that purpose. ${ }^{15}$ In addition to that the Beijing Rules of 1985 have laid down that the minimum age of accruing criminal responsibility should not be fixed at too low an age level but does not fix any minimum age either. ${ }^{16}$ Also the Havana Rules are silent as to the age limit below which a child shall be criminally liable for infringing the penal law. ${ }^{17}$ The Penal Code, 1860 is the national law in Bangladesh which determines the minimum age of criminal liability and sets the age at nine years. ${ }^{18}$ The Penal Code, 1860 further adds that nothing is an offence which is done by a child above the age of nine years and under twelve years, if he does not possess sufficient maturity to form a rational judgment as to the effect of his conduct. ${ }^{19}$ It, nevertheless, continues to be a difficult task to precisely adjudge the transition from the age of childhood innocence to the age of maturity and full responsibility under the penal law. ${ }^{20}$

\section{THE PROTECTIVE APPROACH:}

Here the term 'protective approach' has been used to indicate the protection afforded to the child offenders from ill-treatment. The Children Act, 2013 contains a number of provisions that can be characterised as protective approach. Some of these key provisions include the prohibition on joint trial of child offenders with adult offenders, prohibition on public trial, prohibition on making particulars public and setting up child affairs desk at the police stations.

\subsection{Prohibition on joint trial:}

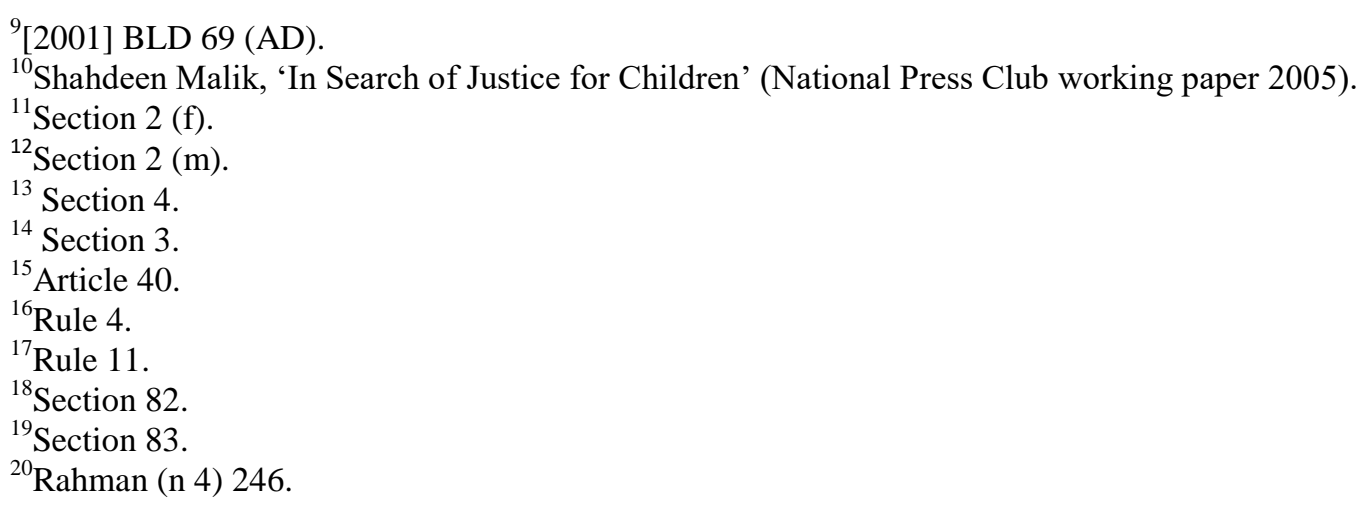

DOI: $10.9790 / 0837-2203064754 \quad$ www.iosrjournals.org $\quad 48 \mid$ Page


None of the international instruments make any compulsion to create separate children's courts and hence, some of the state parties have been loath to try child offenders separately. ${ }^{21}$ Nevertheless, the Children Act, 1974 (hereinafter referred to as the old Act) exempted a child offender from facing a judicial proceeding jointly with an adult. ${ }^{22}$ It was an exception to the general requirement of section 239 of the Code of Criminal Procedure, 1898 to try jointly persons accused of committing the same offence in the same transaction. The Children Act, 2013 also retains the prohibition on joint trial. ${ }^{23}$ Even the Beijing Rules require proceedings involving child offenders to be conducted in an atmosphere which would facilitate their free participation and this provision could be construed to be implicitly requiring a separate trial of child offenders. ${ }^{24}$ The judiciary of Bangladesh has also implemented this provision in numerous cases. In Shiplu and another $v$ State, ${ }^{25}$ Shiplu, who was a child under the old Act was jointly tried with his mother for the commission of murder and they were both convicted. Shiplu preferred an appeal against his conviction on the ground that since he was a child therefore, he should have been tried separately. The appellate court accepted the disposition and set aside the conviction of Shiplu.

The appellate court observed:

Having considering this question in the light of the evidences on record, we held that the trial court failed to apply its judicial mind as to the age of the appellant Shiplu, who appears to be below the age of majority at the time of trial. This makes the order of conviction and sentence passed by the trial court upon appellant Shiplu illegal and the impugned judgment and order are liable to be set aside for want of jurisdiction. ${ }^{26}$

Only two full-fledged children's courts were established under the old Act while other regular courts were from time to time designated to act as children's courts. ${ }^{27}$ The Children Act, 2013 provides for establishing at least one 'children's court' in every district headquarter and in every metropolitan area as the case may be. ${ }^{28}$ The Children Act, 2013 also provides that it is the court of Additional Sessions Judge or in absence of any Additional Sessions Judge, the Court of District and Sessions Judge shall carry out the responsibilities of a children's court. ${ }^{29}$ Accordingly, by gazette notification dated 15/04/2014, a court of Additional Sessions Judge was designated as the first Children's Court. ${ }^{30}$

\subsection{Prohibition on public trials:}

Two of the most significant international human rights instruments, namely the Universal Declaration of Human Rights, $1948^{31}$ and the International Covenant on Civil and Political Rights ${ }^{32}$ have entitled the accused the right to a public trial. Even the Constitution of Bangladesh has enshrined the same principle in its article 35 (3). However, in order to avoid any harm being caused to the child offender, the Children Act, 2013 has only allowed the members and officers of the court, parties to the proceedings, parents or guardians of the child and such other persons as the court thinks fit, to be present during the trial. ${ }^{33}$ The old Act contained identical provisions in Sections 9 and 10 as well.Also the Beijing Rules call for protecting the privacy of the child offenders $^{34}$. In fact this a testament to the fact that judicial proceedings under the Children Act are not just for resolving disputes but also for providing custody, protection and treatment of children. ${ }^{35}$

\subsection{Prohibition on making particulars public:}

The Beijing Rules ${ }^{36}$ as well as the Havana Rules ${ }^{37}$, both prescribe tokeep all the records relating to child offenders confidential. The prospective aim behind this is to facilitate the smooth reintegration of child

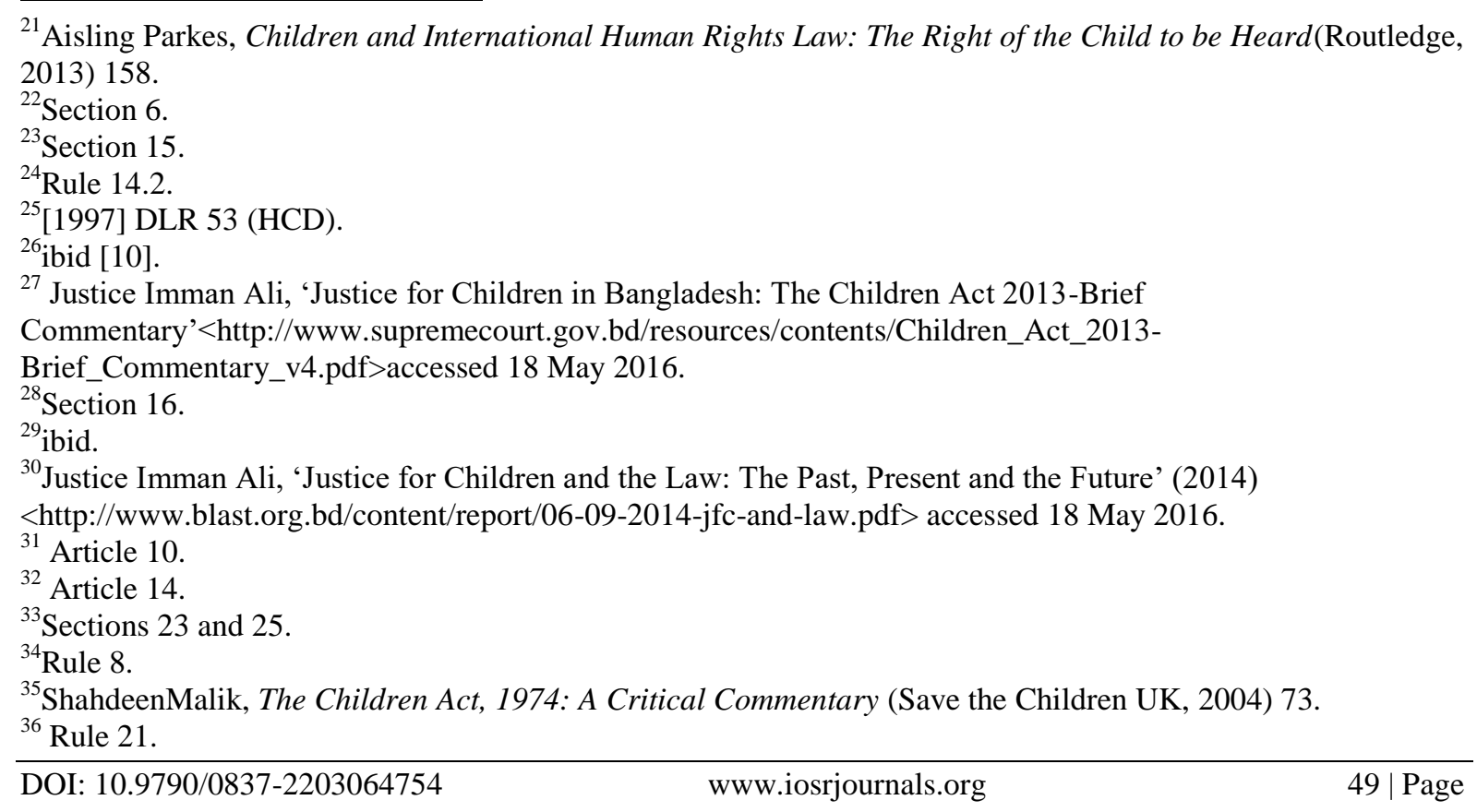


offenders to the society. Acknowledging this principle, the Children Act, 2013 also contains strict prohibition on publication of report disclosing identity of the child concerned in the case. ${ }^{38}$ It is to be noted that even prior to the adoption of relevant international instruments, the old Act also clamped down on publishing reports which may lead to identification of the child concerned. ${ }^{39}$ It may also be mentioned that the Children Act, 2013 penalises publishing any report, photograph or information relating to the trial of the child offender whatsoever in the print or electronic media which may lead to the identification of the child. ${ }^{40}$

\subsection{Setting up child affairs desk at the police station:}

The Children Act, 2013 has incorporated a new provision requiring the establishment of a 'child affairs desk' at every police station. ${ }^{41}$ It states that the Ministry of Home Affairs shall take initiatives to establish a 'Child Affairs Desk' headed by a 'Child Affairs Police Officer' (CAPO), not below the rank of SubInspector. ${ }^{42}$ It further mentions that the CAPO shall maintain separate files and registers for the cases involving children, keep contact with the probation officers and the child's parents or carer, meet the basic needs of the child, determine the age of the child, take diversionary measures and prepare separate charge sheet for child offenders. ${ }^{43}$ These provisions are express reflections of the requirement of specially trained police personnel as mandated in the Beijing Rules ${ }^{44}$ and establishment of special police cell as recommended in State v Secretary, Ministry of Law, Justice and Parliamentary Affairs ${ }^{45}$.

\subsection{Right to legal aid:}

The Beijing Rules augment child offenders the right to be represented by legal counsels. ${ }^{46}$ Articles 37 and 40 of the UNCRC also protect this right. In line with these instruments the Children Act, 2013 also says that they must be represented by legal counsels and in case they or their guardian cannot afford to have a legal counsel, they will be entitled to receive legal aid under the relevant law in force. ${ }^{47}$

\subsection{Determination of the age of a child:}

The old Act said that a child shall not be charged with or tried for any offence jointly with an adult. ${ }^{48}$ The ambiguous wording of the provision split the judiciary into two halves having conflicting views as to its interpretation. In Bablu v State ${ }^{49}$, and in State v Deputy CommissionerSatkhira ${ }^{50}$, the High Court Division held that the date of commission of the offence will be the relevant date to determine whether an accused should be tried as a child or not. However, in Zillur Rahman v State ${ }^{51}$, the Appellate Division took an opposite view and considered the date of framing of the charge or holding the trial as the relevant date for determining whether the accused should be tried as a child or not.The judicial debate intensified as subsequently in RoushanMondal's $\operatorname{case}^{52}$ the High Court Division heavily denounced the position taken by the Appellate Division and strongly emphasised that the date of commission of the offence will rather be the relevant date. The court asserted:

In our humble and respectful view, this misinterpretation arose initially due to the inaptly applied wording of section 6(1) of the Act.... It is the act of the youthful offender done in a moment of indiscretion due to his lesser mental faculty that is being targeted by the Act. Therefore the relevant point in time at which to qualify for the benefits of the Act must be the time of the commission of the offence. ${ }^{53}$ The debacle, however, has now been resolved as the Children Act, 2013 contains an express provision to the effect that the date of the commission of the offence will be relevant to determine the age of the accused. ${ }^{54}$

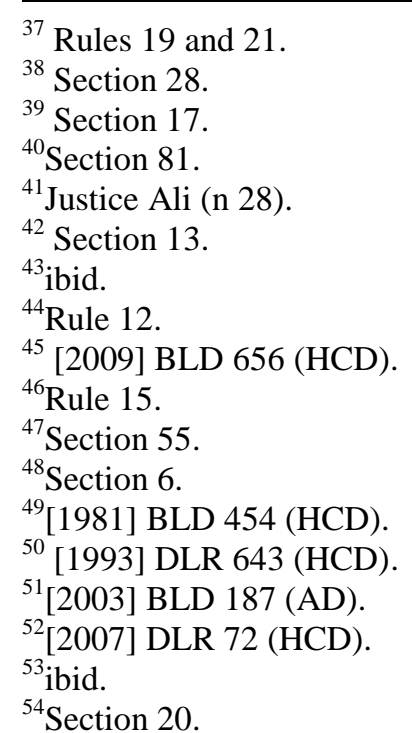

${ }^{54}$ Section 20. 


\section{THE WELFARE APPROACH:}

The term 'welfare approach' refers to the means of exploring the effective ways of reintegrating the child offenders into the society. The Children Act, 2013 provides for adopting various welfare approaches like diversion, family conference, establishment of child development centres and certified institutes and restrained imposition of punishment.

\subsection{Looking at the offender instead of looking at the offence:}

Instead of adjudicating based on the act alone, the children justice jurisprudence appeals to the court to take into account the character, age, circumstances in which the child is living and other matters deemed relevant by it.Both the Beijing Rules ${ }^{55}$ as well as the Havana Rules ${ }^{56}$ require the court to pay due regard to the background of the child and circumstances in which the conduct took place. The old $\mathrm{Act}^{57}$ as well as the present Children Act, $2013^{58}$ have also enumerated these considerations. This point has further been emphasised in State v Deputy Commissioner, Satkhira. ${ }^{59}$

\subsection{Restraint on imposition of punishment:}

The UNCRC ${ }^{60}$, the Beijing Rules ${ }^{61}$, the Havana Rules ${ }^{62}$ and the Riyadh Guidelines ${ }^{63}$ have all put a restraint on imposing any kind of cruel, inhuman and degrading punishment on children. The children justice jurisprudence of Bangladesh has also evolved around the same principles. The old Act prohibited death penalty or imprisonment of a child offender. ${ }^{64}$ The Children Act, 2013 has also retained such prohibition. ${ }^{65}$ Having said that same provisions of both the Acts allowed courts to sentence child offenders to imprisonment in extreme cases which is in consonance with the Beijing Rules ${ }^{66}$ and the Havana Rules ${ }^{67}$.Therefore, this is beyond any doubt that children can under no circumstances be sentenced to death irrespective of how gross the offence might be. ${ }^{68}$

However, it is unfortunate to note that despite the prohibition of death penalty in international instruments as well as in the national legal system, there are a few instances where the courts opted to blatantly overlook such prohibition. Let us critically analyse the Shukur Ali case $e^{69}$ in this context.Shukur Ali, a boy of fourteen, raped and murdered a young girl of seven..$^{70}$ The trial of the case was on the way when he was sixteen and after two years the trial court sentenced him to death. ${ }^{71}$ He made an appeal against his sentence to the High Court Division and the appellate court upheld the death sentence in 2004. ${ }^{72}$ Afterwards, the Appellate Division also confirmed the death sentence in $2005 .^{73}$ The review petition was rejected by the Appellate Division in the same year as well. ${ }^{74}$ It is interesting to note that despite being a child under the existing law the trial was held under the Prevention of Repression of Women and Children Act. At this stage Bangladesh Legal Aid and Services Trust (BLAST) got involved and challenged the validity of the law. The High Court Division partly allowed the petition in 2010 as it declared the law unconstitutional but nevertheless refused to set aside the death penalty. ${ }^{75}$ Being aggrieved, BLAST filed an appeal to the Appellate Division but the death sentence was upheld

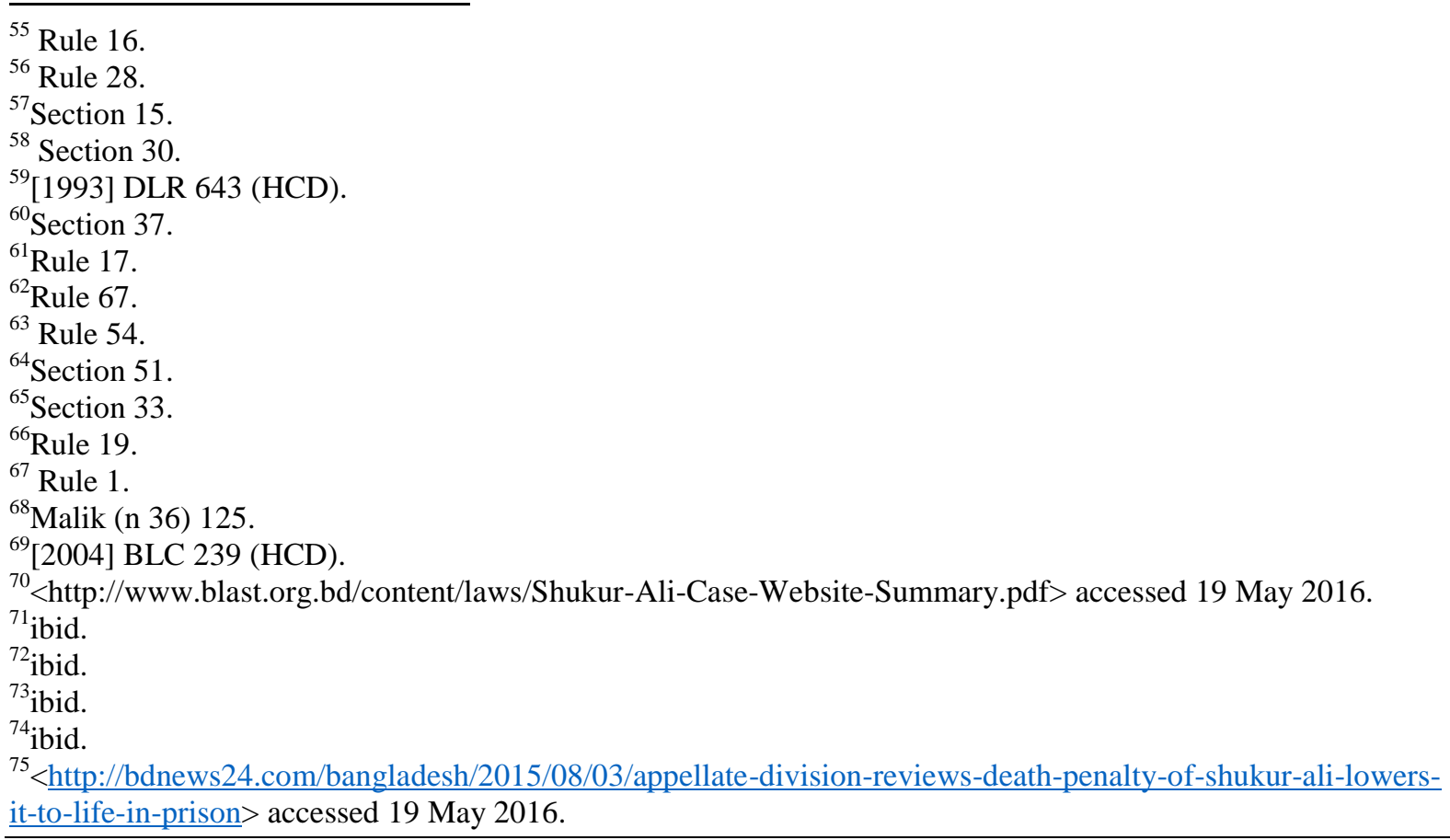

DOI: 10.9790/0837-2203064754 www.iosrjournals.org $\quad$ 51|Page


again in 2015 considering the young age of the victim and the brutal nature of the offence. ${ }^{76}$ BLAST filed a review petition as a last resort and finally the Appellate Division commuted his death penalty to a life time imprisonment on the ground that Shukur Ali was a child at the time of the offence. ${ }^{77}$

Thus finally the gross violation of the provisions relating to the prohibition of imposition of death penalty on children have been rectified.

\subsection{Diversion, family conference and alternative dispute resolution:}

The Beijing Rules have encouraged in appropriate cases to deal with child offenders outside of the court proceedings. ${ }^{78}$ The old Act did not recognise the concepts of diversion, family conference and alternative dispute resolution but the Children Act, 2013 has provided for diversion ${ }^{79}$, family conference ${ }^{80}$ and alternative dispute resolution ${ }^{81}$.

According to the provisions of the Children Act, 2013 diversionary measures may be preferred to a formal criminal proceedings as regards a child offender at any stage starting from the arrest. The case may be sent to the probation officer and in that case he will meet the guardian of such child and inform the CAPO as well as the Children's Court.

Besides the Children Act, 2013 also authorises the probation officer to take necessary steps to arrange a family conference once diversionary measures have been initiated. There is no hard and fast procedures to be followed in a family conference but if the court or the CAPO specifies the steps to be adhered to, the probation officer will act accordingly. If the family conference ends without reaching a solution, the court or the CAPO will have to be informed about it and they will decide what other diversionary measures may be adopted.

\subsection{Establishing child development centres and certified institutes:}

The Havana Rules urges to establish open detention facilities for child offenders. ${ }^{82}$ The Children Act, 2013 has taken queue from the Havana Rules and requires the government to form and supervise adequate number of Child Development Centres based on gender disaggregation for the accommodation, reformation and development of child offenders. ${ }^{83}$ Certified institutes may also be established under the auspices of authorised private authorities. ${ }^{84}$ Such institutes will be inspected by the government and the Director General of the Department of Social Welfare in order to collect necessary information and may advise the government accordingly. ${ }^{85}$ However, be it a government establishment or private establishment, all development centres and institutes will have to keep the Department of Social Welfare up to date regarding the details of the children therein. ${ }^{86}$

In consonance with the requirement of Rule 27 of the Havana Rules, the Children Act, 2013 also sets a minimum standard of care to be maintained in the development centres and the institutes. ${ }^{87}$

\subsection{Periodic review and release:}

Under the heading of non-institutional treatment, the Beijing Rules have incorporated the provision of periodic review and release. ${ }^{88}$ The Children Act, 2013 also creates an obligation upon the Children's Court to stipulate in every order that the order may be subject to periodical review and the child offender may even be released with or without any condition. ${ }^{89}$

\section{FINDINGS AND RECOMMENDATIONS:}

First of all, the actors of the children justice jurisprudence have inadequate knowledge in this field. Although the Children Act, 2013 requires every police station to maintain a child affairs desk and to have a

\footnotetext{
${ }^{76}$ ibid.

${ }^{77}$ ibid.

${ }^{78}$ Rule 11.

${ }^{79}$ Section 48.

${ }^{80}$ Section 49.

${ }^{81}$ Section 37.

${ }^{82}$ Rule 30.

${ }^{83}$ Section 59.

${ }^{84}$ Section 60.

${ }^{85}$ Section 64.

${ }^{86}$ Section 62.

${ }^{87}$ Sections 84 and 85.

${ }^{88}$ Rule 23.

${ }^{89}$ Section 35.
} 
CAPO in that desk, till now not a single child affairs desk has been set up. ${ }^{90}$ Moreover, it is often published in newspapers that children below the age of accruing criminal responsibility are being arrested by the police and sent to the prison by the court. ${ }^{91}$ Continuous trainings, seminars and workshops should be arranged involving the actors so that they become better acquainted with the legal requirements.

The number of child development centres and certified institutes is sparse. In the whole of Bangladesh, there are at present only three development centres of which two are for boys-one is at Tongi while the other is in Jessoreand the solitary establishment for girls is at Konabari of Gazipur district. ${ }^{92}$ In a country with sixty four districts, this is clearly inadequate and as a result the children therein do not have regular communication with their parents. At least one establishment should be set up in every divisional head-quarter to redress this situation. In particular, in case of economic constraint, the government should allow private authorities to set up certified institutes. Also these establishments should be equipped with video link facilities so that they can have access to parents in outlying districts. As an alternative measure, 'kinship care' system should be available to the petty child offenders in which they may be put under the close supervision of their parents, or any relative or even foster parents.

Although, the Additional Sessions Judges have been empowered as the Children's Court within their own respective jurisdictions, there is a popular belief that the wrong court has been chosen for this purpose. The Courts of Additional Sessions Judge are arguably the busiest courts in the country and therefore, either a Children's Court exclusively dealing with child offenders should be established or a less busy should be empowered as Children's Court.

The Children Act, 2013 has authorised the government to frame rules for attaining the objectives of the Act. ${ }^{93}$ However, as of now the government has not come up with the Children Rules. So the government should adopt the rules as early as possible.

\title{
VI. CONCLUSION
}

It can be derived from the preceding study that adequate legal provisions have been adopted over a period of time to foster the children justice jurisprudence in Bangladesh. In particular, many of the provisions of the Children Act, 2013 are in conformity with the UNCRC, the Beijing Rules, the Havana Rules and the Riyadh Guidelines. However, it is regrettable to see that the actors involved are unaware of the legal provisions. Nevertheless, the judiciary, particularly the higher judiciary in recent times have played a pivotal role to enhance the protection of the rights of child offenders in Bangladesh. The civil society as well as the international community should also extend their support to the government. Therefore, it would not be an exaggeration to claim that despite certain disappointments, Bangladesh has been on the right track to uphold the rights of child offenders, albeit slowly.

\section{United Nations Documents}

\section{REFERENCES}

UN General Assembly, Convention on the Rights of the Child, 20 November 1989, United Nations Treaty Series, 1577,3 .

UN General Assembly, United Nations Standard Minimum Rules for the Administration of Juvenile Justice ("The Beijing Rules"): resolution / adopted by the General Assembly., 29 November 1985, A/RES/40/33.

UN General Assembly, United Nations Guidelines for the Prevention of Juvenile Delinquency (The Riyadh Guidelines): resolution / adopted by the General Assembly. , 28 March 1991, A/RES/45/112.

UN General Assembly, United Nations Rules for the Protection of Juveniles Deprived of Their Liberty: resolution / adopted by the General Assembly., 2 April 1991, A/RES/45/113.

\author{
Domestic Cases \\ Bablu v State[1981] BLD 454 (HCD) \\ State v Deputy CommisiionerSatkhira[1993] DLR 643 (HCD) \\ Bimal Chandra $v$ State[1994] DLR 460 (HCD) \\ Shiplu and another $v$ State[1997] DLR 53 (HCD) \\ H.M. Ershad v Bangladesh [2001] BLD 69 (AD) \\ Zillur Rahman v State[2003] BLD 187 (AD)
}

\footnotetext{
${ }^{90}$ Think Legal, 'Think Legal Lecture Series: Rights of Children in Bangladesh \& the Children Act, 2013' (9 June 2015) <www.youtube.com/watch?v=7VTXjfzfuRM> accessed 20 May 2016.

91 ibid.

${ }^{92}$ Abu Noman Mohammad Atahar Ali, ZafrinAndalleb and Abu Saleh Md. TofazzelHaque, 'Towards a Proper Juvenile Justice System in Bangladesh from a Cluttered One: An Analytical Overture on Focusing Human Rights Perspective' (2008) 9 Journal of Human Rights Summer School 241,251. ${ }^{93}$ Section 95 . 
Shukur Ali Case[2004] BLC 239 (HCD)

RoushanMondal's Case[2007] DLR 72 (HCD)

State $v$ Secretary, Ministry of Law, Justice and Parliamentary Affairs[2009] BLD 656 (HCD)

\section{Domestic Legislation}

Constitution of the People's Republic of Bangladesh, 1972

Children Act, 1974

Children Act, 2013

Penal Code, 1860

Prevention of Repression of Women and Children Act, 2002

\section{Books}

Malik S, The Children Act, 1974: A Critical Commentary (Save the Children UK, 2004)

Parkes A, Children and International Human Rights Law: The Right of the Child to be Heard (Routledge, 2013)

\section{Journal Articles}

Ali A N M A, Andaleeb Z and Haque A S M T, 'Towards a Proper Juvenile Justice System in Bangladesh from a Cluttered One: An Analytical Overture on Focusing Human Rights Perspective' (2008) 9 Journal of Human Rights Summer School 241

Rahman A, 'Realization of the Rights of a Child Offender Judicial Activism in Bangladesh' (2008) 9 Journal of Human Rights Summer School 232

\section{Working Paper}

Shahdeen Malik, 'In Search of Justice for Children’ (National Press Club working paper 2015)

\section{Websites}

Justice Imman Ali, 'Justice for Children in Bangladesh: The Children Act 2013-Brief Commentary’<http://www.supremecourt.gov.bd/resources/contents/Children_Act_2013-

Brief_Commentary_v4.pdf>accessed 18 May 2016

Justice Imman Ali, 'Justice for Children and the Law: The Past, Present and the Future' (2014) <http://www.blast.org.bd/content/report/06-09-2014-jfc-and-law.pdf > accessed 18 May 2016

<http://www.blast.org.bd/content/laws/Shukur-Ali-Case-Website-Summary.pdf> accessed 19 May 2016 $<$ http://www.bdnews24.com/bangladesh/2015/08/03/appellate-division-reviews-death-penalty-of-shukur-alilowers-it-to-life-in-prison> accessed 19 May 2016

<http://www.humanium.org/en/asia-pacific/bangladesh/> accessed 16 May 2016

\section{YouTube}

Think Legal, 'Think Legal Lecture Series: Rights of Children in Bangladesh \& the Children Act, 2013' (9 June 2015 ) <www.youtube.com/watch?v=7VTXjfzfuRM> accessed 20 May 2016 